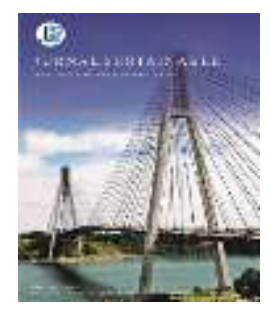

\title{
Desain Alat Pemanen Buah Manggis Melalui Pendekatan Kansei Engineering
}

\author{
Amorita Iqradiella Edytiananda ${ }^{1}$, Wahyu Kristian Sugandi ${ }^{2}$, Ahmad Thoriq ${ }^{2}$, Asep Yusuf ${ }^{2}$ \\ ${ }^{1,2}$ Program Studi Teknik Pertanian, Fakultas Teknologi Industri Pertanian, Universitas Padjadjaran \\ ${ }^{1,2}$ Jalan Raya Bandung - Sumedang km.21 Jatinangor \\ Email : $\underline{\text { amorita.iqradiella@gmail.com }}$
}

\begin{abstract}
Mangosteen fruit harvesting is generally done by climbing trees (manually) and using harvesting tools. Harvesting equipment used is made of bamboo and has several disadvantages, namely the driver of the fruit cannot be set easily, the guide is not adjusted to the size of the mangosteen fruit and also the pole made of bamboo is too long and requires a large enough space, so it is necessary to design a mangosteen harvester. The method used in this research is through Kansei Engineering approach. Kansei Engineering is a method that can determine the desirability of a harvester by searching Kansei Word and the design elements of the harvest tool in the form of a paired questionnaire given to 30 respondents. The results of the analysis show that the design elements selected in the fruit guide are "V" shaped by rotating the harvest (X12), the capacity of the shelter is 1 (one) fruit (X22), the position of the fruit guide is given a bolt as a pole fastener with a place shelter (X31) and telescopic shaped poles (X42).
\end{abstract}

Keywords - Mangosteen, Harvest Tool, Kansei Engineering, Kansei Word, Elements Design.

\begin{abstract}
Intisari - Pemanenan buah manggis umumnya dilakukan dengan cara memanjat pohon (manual) dan menggunakan alat panen. Alat panen yang digunakan terbuat dari bambu dan memiliki beberapa kelemahan yaitu pengarah buah tidak dapat diatur dengan mudah, pengarah buat tidak disesuaikan dengan ukuran buah manggis dan juga galah yang terbuat dari bambu terlalu panjang dan membutuhkan ruang yang cukup besar, sehingga perlu dirancang alat pemanen manggis. Metode yang digunakan pada penelitian ini yaitu melalui pendekatan kansei engineering. Kansei Engineering merupakan metode yang dapat mengetahui keinginan desain dari pemanen yang dilakukan dengan mencari Kansei Word dan elemen desain dari alat panen dalam bentuk kuisioner berpasangan yang diberikan kepada 30 responden. Hasil analisis menunjukkan bahwa elemen desain yang terpilih pada pengarah buah yaitu berbentuk " $\mathrm{V}$ " dengan cara panen di putar (X12), kapasitas tempat penampungan yaitu 1 (satu) buah (X22), pada kedudukan pengarah buah yaitu diberi baut sebagai pengikat galah dengan tempat penampungan (X31) dan galah berbentuk teleskopik (X42).
\end{abstract}

Kata kunci - Manggis, Alat Panen, Kansei Engineering, Kansei Word, Elemen Desain

\section{Pendahuluan}

Petani manggis sebagian besar melakukan pemanenan dengan cara sangat sederhana, yaitu memetik buah yang masih terjangkau dengan tangan, sedangkan yang tidak terjangkau pemanenannya dilakukan menggunakan galah yang terbuat dari bambu [1]. Hal tersebut merupakan permasalahan yang cukup kompleks sehingga perlu dilakukannya desain alat pemanen manggis. Desain alat pemanen manggis dirancang berdasarkan keinginan pengguna (pemanen) dengan menggunakan metode rekayasa Kansei (Kansei Engineering). 
A. I. Edytiananda, W. K. Sugandi, A. Thoriq dan A. Yusuf, Desain Alat Pemanen Buah Manggis Melalui Pendekatan Kansei Engineering

Rekayasa Kansei (Kansei Engineering) diperkenalkan oleh Prof. Dr. Mitsuo Nagamachi pada tahun 1995 dan kemudian dikembangkan oleh Prof. Dr. Haruchiko Murase pada tahun 2004 hingga sekarang [2]. Metode Kansei Engineering menggunakan penilaian pengguna terhadap produk yang akan didesain sebagai cara untuk memperoleh keinginan pengguna [3].

Penelitian dilakukan melalui beberapa tahap, untuk tahap pertama yaitu tahap pendahuluan yang dilakukan melalui studi pustaka (rekayasa Kansei, AHP dan buah manggis), survey lapang (wawancara kepada petani buah manggis untuk memperoleh gambaran umum mengenai alat pemanen yang digunakan) dan penentuan jenis produk (penetapan produk yang menjadi obyek penelitian yaitu alat pemanen). Tahap kedua adalah tahap pengolahan data dengan pengumpulan Kansei word (wawancara kepada petani, literatur yang berkaitan dengan alat pemanen) kemudian mengelompokkan Kansei word berdasarkan kesamaan arti kata sehingga menghasilkan Kansei word yang mewakili kata lain berdasarkan pemilihan prioritas. Tahap pengumpulan data juga dilakukan tahap pengumpulan desain alat pemanen berdasarkan alat yang telah digunakan oleh petani dan juga beberapa penelitian mengenai desain alat pemanen sehingga menghasilkan elemen desain dari alat pemanen tersebut. Tahap terakhir adalah tahap evaluasi dengan mengolah data dan menganalisis hasil dari penentuan desain elemen alat pemanen berdasarkan kansei word.

\section{Metode Penelitian}

\section{A. Alat, Bahan dan Subjek Penelitian}

Peralatan yang digunakan untuk keperluan data pada penelitian ini yaitu Kuisioner untuk mendapatkan data Kansei Word, Software Expert Choice untuk mengolah data hasil dari Kansei Word dan elemen desain, sedangkan untuk mendesain hasil rancangan penelitian menggunakan Software SolidWorks.

Bahan baku yang digunakan pada penelitian ini yaitu buah manggis yang belum dipanen. Bahan-bahan yang digunakan untuk analisis yaitu hasil Kansei Word dan elemen desain, gambar teknik hasil desain dan analisis teknik alat hasil desain. Pada penelitian ini menggunakan data primer yang diperoleh dari pengukuran secara langsung melalui kuisioner, wawancara yang dilakukan kepada Subjek Penelitian (Petani) dan turun langsung ke lapangan. Subjek penelitian yang diamati adalah 30 orang petani yang melakukan pemanenan manggis dengan berjenis kelamin laki-laki agar dapat mendesain alat pemanen manggis yang sesuai dengan kebutuhan petani manggis

\section{B. Metode Penelitian}

Metode penelitian yang digunakan pada penelitian ini yaitu menggunakan metode rekayasa. Metode rekayasa diperoleh berdasarkan data dari rekayasa kansei. Tahapan yang dilakukan dalam penelitian ini sesuai dengan diagram alir yang disajikan pada Gambar 1, meliputi perancangan dan penyebaran kuisioner, pengumpulan elemen desain alat pemanen manggis, pengumpulan data Kansei Words, pembuatan desain alat pemanen manggis dan uji kinerja hasil alat pemanen manggis.

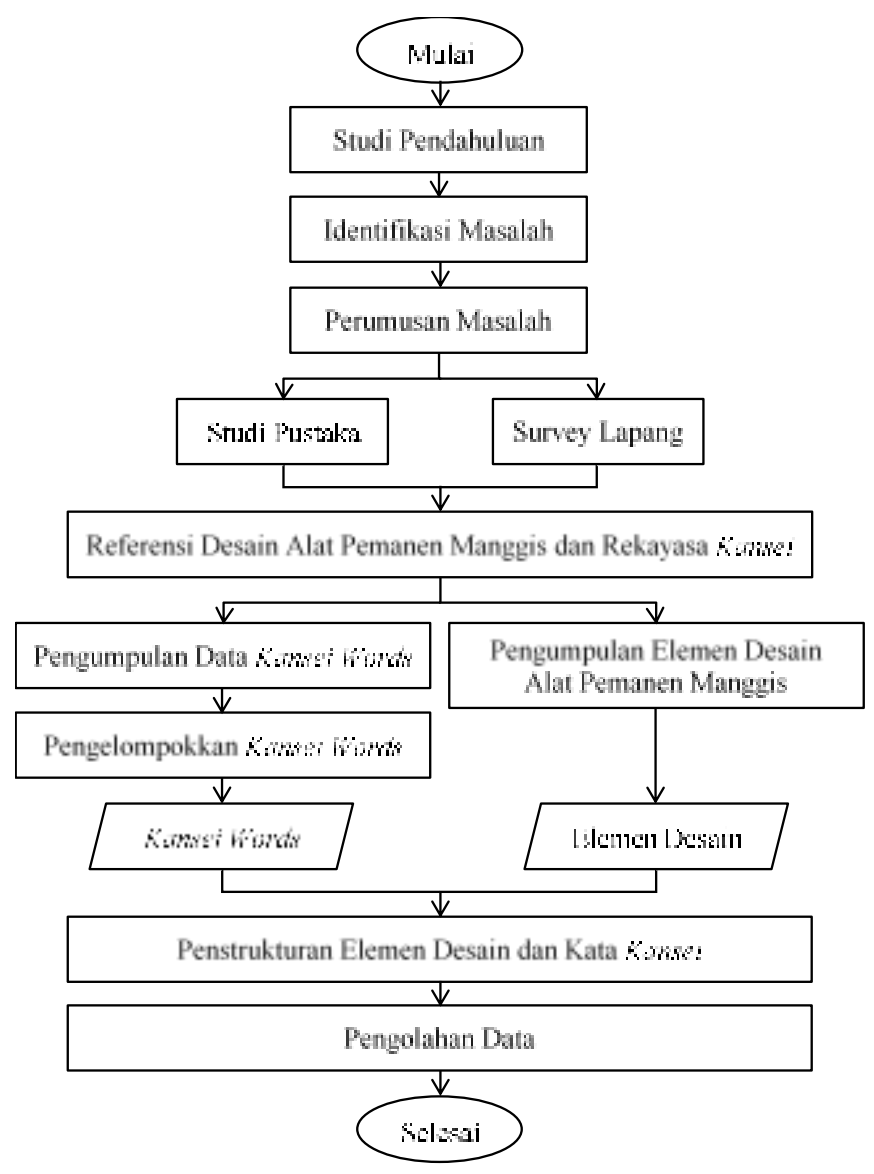

Gambar 1. Diagram Alir Tahapan Penelitian 


\section{Hasil dan PeMbahasan}

\section{A. Elemen Desain}

Elemen desain dilakukan dengan cara mengumpulkan gambar desain produk dari beberapa alat pemanen buah yang banyak dirancang atau didesain oleh beberapa penelitian. Gambar dan bentuk dari beberapa desain alat panen kemudian diklasifikasikan berdasarkan elemen-elemen desainnya, yaitu pengarah buah, tempat penampungan, kedudukan pengarah buah dan galah. Beberapa elemen desain yang sesuai dan dapat digunakan pada alat pemanen manggis disajikan pada Tabel 1 .

Tabel 1. Bentuk Elemen Desain Alat Pemanen

\begin{tabular}{|c|c|c|c|}
\hline $\begin{array}{c}\text { Elemen } \\
\text { Desain }\end{array}$ & Kode & Bentuk & Keterangan \\
\hline $\begin{array}{c}\text { Pengarah } \\
\text { Buah }\end{array}$ & X12 & & $\begin{array}{c}\text { Berbentuk "U" } \\
\text { dengan cara panen } \\
\text { di tarik } \\
\text { Berbentuk "V" } \\
\text { dengan cara panen } \\
\text { di putar }\end{array}$ \\
\hline & $\mathrm{X} 14$ & & $\begin{array}{l}\text { Berbentuk "M" } \\
\text { yang dilengkapi } \\
\text { pisau peringis } \\
\text { dengan cara panen } \\
\text { di tarik } \\
\text { Terdapat capit di } \\
\text { ujung berbentuk } \\
\text { "W" dengan cara } \\
\text { panen di tarik }\end{array}$ \\
\hline & $\mathrm{X} 15$ & & $\begin{array}{l}\text { Terdapat capit di } \\
\text { ujung berbentuk } \\
\text { " } \text { " dengan cara } \\
\text { panen di tarik }\end{array}$ \\
\hline $\begin{array}{l}\text { Tempat } \\
\text { Penampu } \\
\text { ngan }\end{array}$ & $\mathrm{X} 21$ & & $\begin{array}{l}\text { Berbentuk oval } \\
\text { dengan kapasitas } \\
\text { 3-4 buah }\end{array}$ \\
\hline & $\mathrm{X} 22$ & & $\begin{array}{l}\text { Berbentuk kerucut } \\
\text { terbalik dengan } \\
\text { kapasitas } 1 \text { buah }\end{array}$ \\
\hline & $\mathrm{X} 23$ & & $\begin{array}{c}\text { Kapasitas } 3-4 \\
\text { buah }\end{array}$ \\
\hline & $\mathrm{X} 24$ & 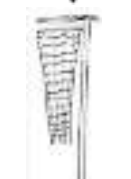 & $\begin{array}{c}\text { Kapasitas 1-2 dan } \\
\text { buah akan } \\
\text { langsung jatuh } \\
\text { kebawah }\end{array}$ \\
\hline
\end{tabular}

$\begin{gathered}\text { Kedudukan } \\ \text { Pengarah } \\ \text { Buah }\end{gathered}$
X31

Pemilihan elemen desain dilakukan dengan cara penyebaran kuesioner ke 30 responden (petani) berjenis kelamin laki-laki dengan umur bervariasi antara 30-67 tahun. Dimana petani tersebut memilih elemen desain pada alat pemanen manggis yang menurut mereka lebih disukai.

\section{B. Kansei Word}

Identifikasi Kansei dilakukan dengan pengukuran Kansei melalui kata-kata yang mengungkapkan perasaan dan emosi pengguna (pemanen). Pada penelitian ini, kata-kata yang berhasil di kumpulkan berjumlah 30 Kata yang berasal dari wawancara kepada petani manggis dan literatur yang berkaitan alat pemanen manggis dengan menunjukkan perasaan dan emosi dari pengguna pemanen tersebut. 
A. I. Edytiananda, W. K. Sugandi, A. Thoriq dan A. Yusuf, Desain Alat Pemanen Buah Manggis Melalui Pendekatan Kansei Engineering

Kata-kata Kansei yang sebanyak 30 kata dilakukan pengelompokan secara manual berdasarkan kesamaan arti kata yang dikurangi menjadi 8 kata melalui proses brainstorming dengan pakar yang terdiri dari satu orang staf pengajar Unpad dan satu orang ketua kelompok petani manggis. Kansei word tersebut disajikan pada Tabel 2.

Tabel 2. Data Kansei Word Alat Pemanen

\begin{tabular}{ccc}
\hline Kode & Kriteria & Kansei Word \\
\hline $\mathbf{Y}_{\mathbf{1}}$ & Ekonomis & Murah \\
$\mathbf{Y}_{\mathbf{2}}$ & & Tahan Lama \\
\hline $\mathbf{Y}_{\mathbf{3}}$ & Fungsional & Nyaman \\
$\mathbf{Y}_{\mathbf{4}}$ & & Mudah Digunakan \\
\hline $\mathbf{Y}_{\mathbf{5}}$ & Manufaktur & Ringan \\
$\mathbf{Y}_{\mathbf{6}}$ & & Perawatan Mudah \\
\hline $\mathbf{Y}_{\mathbf{7}}$ & Struktural & Kuat \\
$\mathbf{Y}_{\mathbf{8}}$ & & Sederhana \\
\hline
\end{tabular}

Kansei word yang mempunyai pengertian yang sama dikelompokkan dan kemudian dilakukan pemilihan prioritas satu atau dua kata yang dapat mewakili kata lain.

\section{Penstrukturan Nilai Prioritas Desain Alat Pemanen}

Penstrukturan nilai prioritas dilakukan dengan menggunakan metode Analytical Hierarchy Process (AHP) dengan membaginya ke dalam unsur-unsur berupa kriteria dan alternative serta menyusunnya menjadi struktur hirarki. Struktur hirarki dibagi menjadi tiga unsur yaitu tujuan, faktor, dan Kansei Word.

Nilai kepentingan diperoleh dengan mengolah hasil kuisioner dengan pairwise comparison (perbandingan berpasangan) menggunakan bantuan Software Expert Choice 11. Struktur hirarki dibagi menjadi tiga unsur, yaitu tujuan, faktor, dan kata Kansei seperti yang disajikan pada Gambar2.

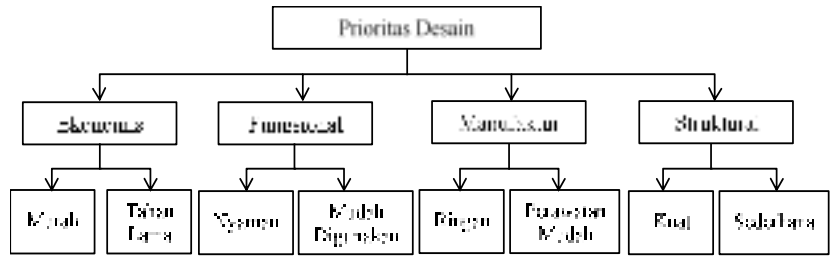

Gambar 2. Struktur Hirarki Pemilihan Prioritas Desain Alat Panen

Pada desain pengarah buah, hasil olahan data kuisioner diperoleh bobot faktor yang mempengaruhi Kansei Konsumen tertinggi adalah faktor fungsional dengan bobot 0,477. Prioritas kata Kansei konsumen untuk desain pengarah buah adalah tahan lama dengan bobot 0,741 . Secara jelas bobot faktor untuk desain pengarah buah disajikan pada Tabel 3 .

Tabel 3. Bobot Faktor Pengarah Buah

\begin{tabular}{|c|c|c|c|c|c|}
\hline Faktor & Bobot & $\begin{array}{c}\text { Ting } \\
\text { kat }\end{array}$ & Kata & Bobot & $\begin{array}{c}\text { Ting } \\
\text { kat }\end{array}$ \\
\hline \multirow[t]{2}{*}{ Ekonomis } & 0,327 & 2 & Murah & 0,259 & 8 \\
\hline & & & Tahan Lama & 0,741 & 1 \\
\hline \multirow[t]{2}{*}{ Fungsional } & 0,477 & 1 & Nyaman & 0,459 & 5 \\
\hline & & & $\begin{array}{c}\text { Mudah } \\
\text { Digunakan }\end{array}$ & 0,541 & 4 \\
\hline \multirow[t]{2}{*}{ Manufaktur } & 0,073 & 4 & Ringan & 0,551 & 3 \\
\hline & & & $\begin{array}{c}\text { Perawatan } \\
\text { Mudah }\end{array}$ & 0,449 & 6 \\
\hline \multirow[t]{2}{*}{ Struktural } & 0,124 & 3 & Kuat & 0,602 & 2 \\
\hline & & & Sederhana & 0,398 & 7 \\
\hline
\end{tabular}

Hasil pemilihan alternatif terhadap desain alat pemanen manggis menunjukkan desain pengarah buah berbentuk "V" dengan cara panen di tarik (X12) menjadi prioritas pertama dengan bobot 0,454. Secara lebih jelas bobot hasil pemilihan alternatif desain dengan menggunakan pairwise comparison disajikan pada Gambar 3.

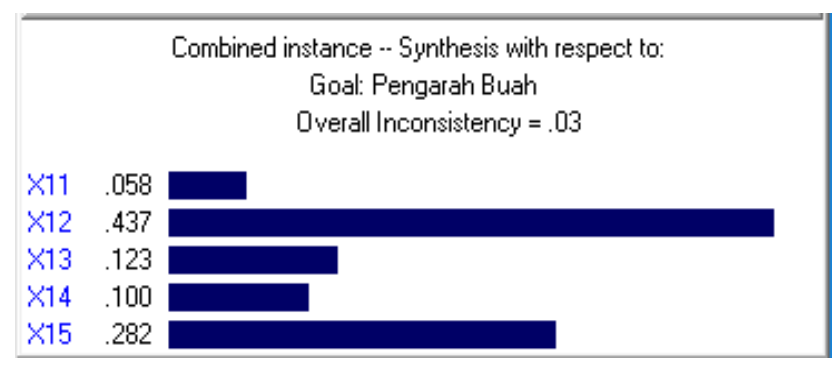

Gambar 3. Prioritas Elemen Desain Pengarah Buah

Pada desain tempat penampungan, hasil olahan kuisioner diperoleh bobot faktor yang mempengaruhi Kansei Konsumen tertinggi adalah faktor fungsional dengan bobot 0,468. Prioritas kata Kansei konsumen untuk desain tempat penampungan adalah tahan lama dengan bobot 0,787 . Secara jelas bobot faktor untuk 
desain tempat penampungan disajikan pada Tabel 4.

Tabel 4. Bobot Faktor Tempat Penampungan

\begin{tabular}{|c|c|c|c|c|c|}
\hline Faktor & Bobot & $\begin{array}{l}\text { Ting } \\
\text { kat }\end{array}$ & Kata & Bobot & $\begin{array}{l}\text { Ting } \\
\text { kat }\end{array}$ \\
\hline \multirow[t]{2}{*}{ Ekonomis } & 0,354 & 2 & Murah & 0,213 & 8 \\
\hline & & & Tahan Lama & 0,787 & 1 \\
\hline \multirow[t]{3}{*}{ Fungsional } & 0,468 & 1 & Nyaman & 0,487 & 6 \\
\hline & & & Mudah & 0,513 & 3 \\
\hline & & & Digunakan & & \\
\hline \multirow[t]{2}{*}{ Manufaktur } & 0,068 & 4 & Ringan & 0,501 & 4 \\
\hline & & & $\begin{array}{l}\text { Perawatan } \\
\text { Mudah }\end{array}$ & 0,499 & 5 \\
\hline \multirow[t]{2}{*}{ Struktural } & 0,110 & 3 & Kuat & 0,605 & 2 \\
\hline & & & Sederhana & 0,395 & 7 \\
\hline
\end{tabular}

Hasil pemilihan alternatif terhadap desain alat pemanen manggis menunjukkan desain tempat penampungan berbentuk kerucut terbalik dengan kapasitas 1 buah (X22) menjadi prioritas pertama dengan bobot 0,486. Secara lebih jelas bobot hasil pemilihan alternatif desain dengan menggunakan pairwise comparison disajikan pada Gambar 4.

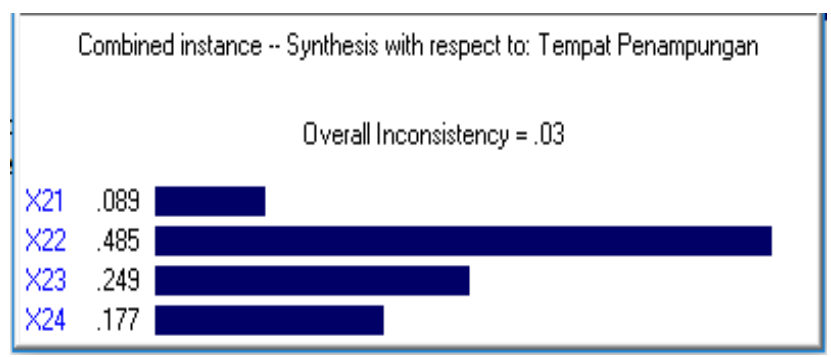

Gambar 4. Prioritas Elemen Desain Tempat Penampungan

Tabel 5. Bobot Faktor Kedudukan Pengarah Buah

\begin{tabular}{cccccc}
\hline Faktor & Bobot & $\begin{array}{c}\text { Ting } \\
\text { kat }\end{array}$ & Kata & Bobot & $\begin{array}{c}\text { Ting } \\
\text { kat }\end{array}$ \\
\hline Ekonomis & 0,296 & 2 & Murah & 0,213 & 8 \\
& & & Tahan Lama & 0,787 & 1 \\
Fungsional & 0,473 & 1 & $\begin{array}{c}\text { Nyaman } \\
\text { Mudah }\end{array}$ & 0,487 & 5 \\
& & & 0,513 & 4 \\
Manufaktur & 0,076 & \multirow{4}{*}{$\begin{array}{c}\text { Digunakan } \\
\text { Ringan }\end{array}$} & 0,528 & 3 \\
& & & $\begin{array}{c}\text { Perawatan } \\
\text { Mudah }\end{array}$ & 0,427 & 6 \\
Struktural & 0,155 & 3 & Kuat & 0,605 & 2 \\
& & & Sederhana & 0,395 & 7 \\
\hline
\end{tabular}

Pada desain kedudukan pengarah buah, hasil olahan data kuisioner diperoleh bobot faktor yang mempengaruhi Kansei Konsumen tertinggi adalah faktor fungsional dengan bobot 0,473. Prioritas kata Kansei konsumen untuk desain kedudukan pengarah buah adalah tahan lama dengan bobot 0,787 . Secara jelas bobot faktor disajikan pada Tabel 5.Hasil pemilihan alternatif terhadap desain alat pemanen manggis menunjukkan desain kedudukan pengarah buah diberi baut sebagai pengikat galah dengan tempat penampungan (X31) menjadi prioritas pertama dengan bobot 0,477 . Secara lebih jelas bobot hasil pemilihan alternatif desain dengan menggunakan pairwise comparison disajikan pada Gambar 5.

\section{Combined instance - Syynthesis with respect to: \\ Kedudukan Pengarah Buah \\ Overall Inconsistency $=.02$}

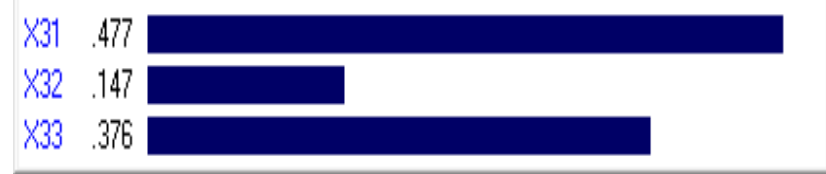

Gambar 5. Prioritas Elemen Desain Kedudukan Pengarah Buah

Pada desain galah, hasil olahan data kuisioner diperoleh bobot faktor yang mempengaruhi Kansei Konsumen tertinggi adalah faktor fungsional dengan bobot 0,429. Prioritas kata Kansei konsumen untuk desain galah adalah tahan lama dengan bobot 0,487. Secara jelas bobot faktor untuk desain galah disajikan pada Tabel 6 .

Tabel 6. Bobot Faktor Galah

\begin{tabular}{cccccc}
\hline Faktor & Bobot & $\begin{array}{c}\text { Ting } \\
\text { kat }\end{array}$ & Kata & Bobot & $\begin{array}{c}\text { Ting } \\
\text { kat }\end{array}$ \\
\hline Ekonomis & 0,292 & 2 & Murah & 0,213 & 8 \\
& & & Tahan Lama & 0,787 & 1 \\
Fungsional & 0,429 & 1 & $\begin{array}{c}\text { Nyaman } \\
\text { Mudah }\end{array}$ & 0,487 & 6 \\
& & & 0,513 & 3 \\
Manufaktur & 0,162 & 3 & $\begin{array}{c}\text { Digunakan } \\
\text { Ringan }\end{array}$ & 0,493 & 5 \\
& & & $\begin{array}{c}\text { Perawatan } \\
\text { Mudah }\end{array}$ & 0,507 & 4 \\
Struktural & 0,116 & 4 & Kuat & 0,605 & 2 \\
& & & Sederhana & 0,395 & 7 \\
\hline
\end{tabular}

Hasil pemilihan alternatif terhadap desain alat panen manggis menunjukkan desain galah berbentuk teleskopik yang dapat diatur panjang dan pendeknya (X41) menjadi prioritas pertama dengan bobot 0,731 . Pemilihan alternatif yang menjadi prioritas kedua yaitu menunjukkan galah yang terbuat dari bambu (X42) yang memiliki bobot 0,269 . Secara lebih jelas bobot hasil pemilihan alternatif desain dengan 
A. I. Edytiananda, W. K. Sugandi, A. Thoriq dan A. Yusuf, Desain Alat Pemanen Buah Manggis Melalui Pendekatan Kansei Engineering

menggunakan pairwise comparison disajikan pada Gambar 6.

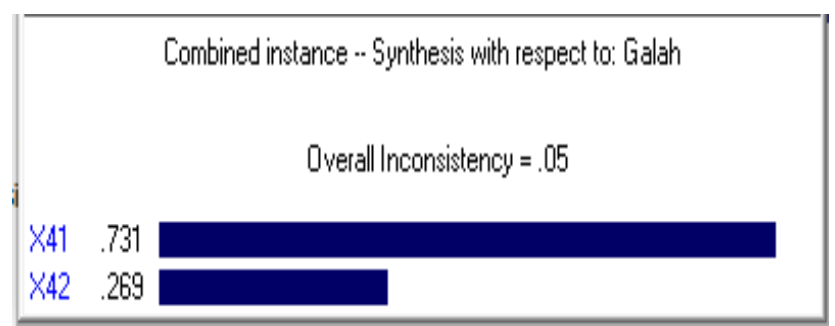

Gambar 6. Prioritas Elemen Desain Galah

\section{Pemeriksaan Kesesuaian Perbandingan Berpasangan}

Pemeriksaan kesesuaian perbandingan berpasangan diperoleh dari nilai hasil pembobotan masing-masing kriteria dan alternatif. Penilaian dan penentuan tingkat prioritas dilakukan secara subjektif, maka pengambilan keputusan menggunakan AHP harus konsisten. Pengukuran tingkat konsistensi dapat dilakukan langsung dengan menggunakan Software Expert Choice pada semua elemen desain yaitu pengarah buah, tempat penampungan, kedukan pengarah buah dan galah. Jika nilai rasio konsistensi (CR) yang lebih kecil atau sama dengan 0,1 merupakan nilai yang memiliki tingkat konsistensi baik dan dapat dipertanggungjawabkan.

Konsistensi pembobotan pada elemen desain pengarah buah menunjukkan angka 0,04 yang menyatakan konsistensi pembobotan kurang dari 0,1 sehingga hasil pembobotan dianggap memenuhi persyaratan inkonsistensi atau pembobotan dilakukan secara konsisten. Nilai rasio konsistensi pada elemen desain pada pengarah buah dapat dilihat pada Gambar 7 .

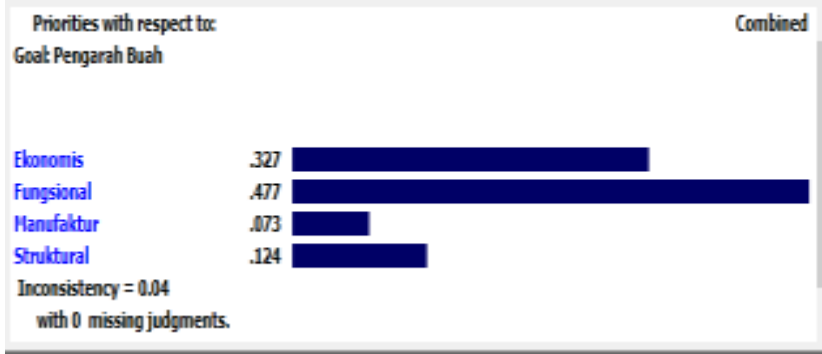

Gambar 7. Nilai Rasio Konsistensi Pengarah Buah

Konsistensi pembobotan pada elemen desain tempat penampungan juga menunjukkan angka 0,04 yang menyatakan konsistensi pembobotan kurang dari 0,1 sehingga hasil pembobotan dianggap memenuhi persyaratan inkonsistensi atau pembobotan dilakukan secara konsisten. Nilai rasio konsistensi pada elemen desain pada tempat penampungan dapat dilihat pada Gambar 8.

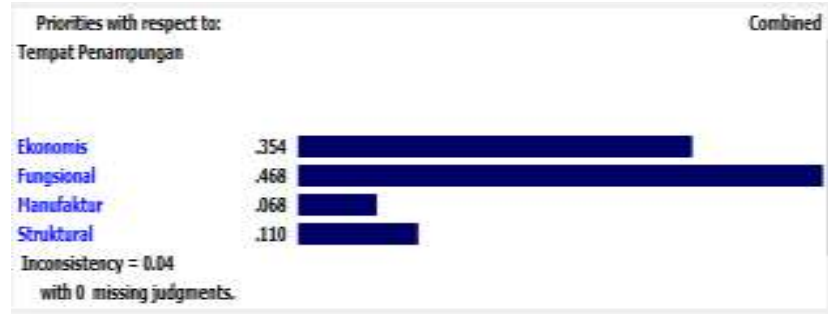

Gambar 8. Nilai Rasio Konsistensi Tempat Penampungan

Konsistensi pembobotan pada elemen desain kedudukan pengarah buah menunjukkan angka 0,03 yang menyatakan konsistensi pembobotan kurang dari 0.1, maka hasil pembobotan dianggap memenuhi persyaratan inkonsistensi atau pembobotan dilakukan secara konsisten. Nilai rasio konsistensi pada elemen desain pada tempat penampungan dapat dilihat pada Gambar 9.

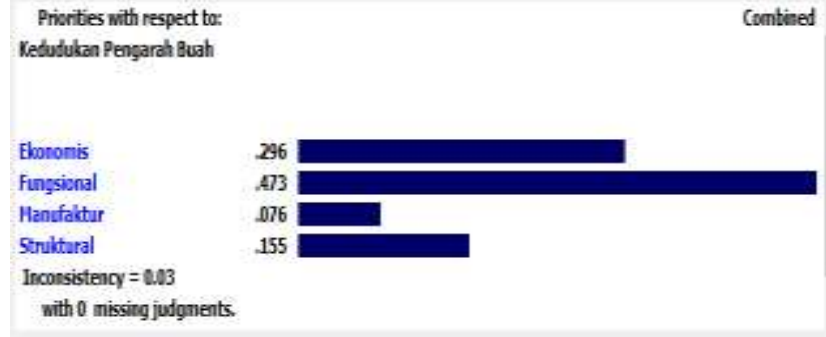

Gambar 9. Nilai Rasio Konsistensi Tangkai Pemetik

Konsistensi pembobotan pada elemen desain kedudukan pengarah buah menunjukkan angka 0,05 yang menyatakan konsistensi pembobotan kurang dari 0,1, maka hasil pembobotan dianggap memenuhi persyaratan inkonsistensi atau pembobotan dilakukan secara konsisten. Nilai rasio konsistensi pada elemen desain pada tempat penampungan dapat dilihat pada Gambar 10.

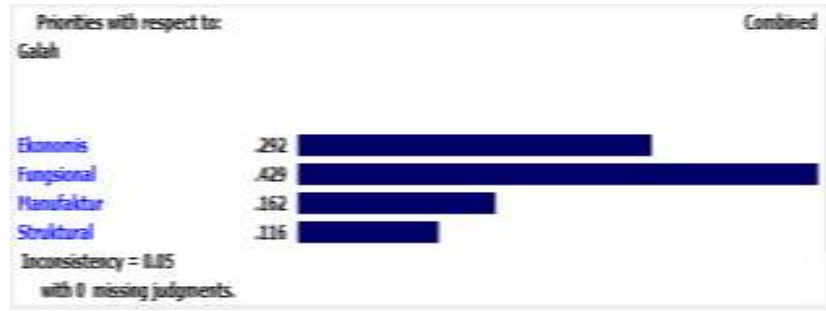

Gambar 10. Nilai Rasio Konsistensi Galah 


\section{KeSIMPULAN}

Pemilihan alternatif desain alat pemanen manggis menggunakan pendekatan rekayasa Kansei Engineering dengan menggunakan metode Analytical Hierarchy Process dan metode rancang bangun, dapat disimpulkan sebagai berikut. Desain alat pemanen manggis berdasarkan pendekatan Kansei Engineering diperoleh hasil pada pengarah atau pengait buah berbentuk "V" dan terbuat dari bambu dengan cara pemanenan di putar. Desain alat pemanen manggis berdasarkan pendekatan Kansei Engineering diperoleh hasil pada tempat penampungan berbahan kayu dengan kapasitas panen 1 buah. Desain alat pemanen manggis berdasarkan pendekatan Kansei Engineering diperoleh hasil pada tangkai pemetik dengan diberi palang melintang yang terbuat dari alumunium sebagai tempat pengikat galah dengan tangkai pemetik. Desain alat pemanen manggis berdasarkan pendekatan Kansei Engineering diperoleh hasil pada galah berbentuk teleskopik yang dapat diatur panjang dan pendeknya.

\section{REFERENSI}

${ }^{[1]}$ I. P. Gunadnya, I. M. S. Utama and M. S. Mahendra, "Pengaruh Benturan dan Indeks Panen Buah Terhadap Mutu Buah Manggis," Ketekikan Pertanian, vol. 15, no. 1, pp. 2733, 2001.

[2] Suyanti and Setyadjit, "Teknologi Penanganan Buah Manggis Untuk Mempertahankan Mutu Selama Penyimpanan," Teknologi Pascapanen Pertanian, vol. 3, no. 1, pp. 66-73, 2007.

[3] M. Nagamachi, "Perspectives and The New Trend of Kansei or Affective Engineering," The TQM, vol. 20, no. 4, pp. 290-298, 2008.

[4] M. Ushada, A. Suryandono and N. Khuriyati, Kansei Engineering untuk Agroindustri, Yogyakarta: Gajah Mada University Press, 2015. 